U. S. DEPARTMENT OF C ERCE

JESSE H. JONES, Secretary

NATIONAL BUREAU OF STANDARDS

LYMAN J. BRIGGS, Director

CIRCULAR OF THE NATIONAL BUREAU OF STANDARDS C435

[Supersedes Circular C414]

\title{
AMERICAN STANDARD SPECIFICATION FOR DRY CELLS AND BATTERIES
}

\author{
[Issued February 18, 1942] \\ Approved November 28, 1941, by the \\ American Standards Association (ASA designation C18-1941)
}

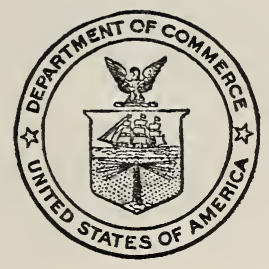

UNITED STATES

GOVERNMENT PRINTING OFFICE

WASHINGTON : 1942

For sale by the Superintendent of Documents, Washington, D. C. - - - - Price 10 cents 


\section{PREFACE}

The publication of the fourth edition of the American Standard Specification for Dry Cells and Batteries marks the completion of another step in the development of a specification which had its inception in the need for a purely governmental standard during the critical years of 1917 and 1918. Since then, manufacturers of dry cells and the largest industrial users of them have cooperated with representatives of the Government in perfecting tests and specifieations for the varied kinds of dry cells and batteries. This work has been accomplished through a Sectional Committee of the American Standards Association, acting under the sponsorship of the National Bureau of Standards.

Within the past few years new types of cells have been developed to meet new industrial uses, and the available output of the better brand's of older types is now three- to four-fold greater than 20 years or more ago. These advances were made possible by the ability and willingness of manufacturers to improve their product. The resulting benefits are shared by the Government and the public alike. The National Bureau of Standards is glad to have a part in this work. Future revisions will undoubtedly become necessary, as they have in the past, because the value of the specifications depends on their keeping pace with advances made in the art.

November 28, 1941

LYMAN J. BRIGGS, Director, National Bureau of Standards. 


\section{HISTORY OF THE PROJECT}

In 1912 a committee ${ }^{1}$ of the American Electrochemical Society recommended standard methods of testing dry cells. Although much has been accomplished in developing specifications for dry cells and batteries since that time, the influence of these early recommendations on some of the later specifications is still discernible.

The preparation of nationally recognized specifications to include sizes of cells, arrangement of batteries, tests, and required performance began in 1917 with the drafting of specifications which were later submitted by the National Bureau of Standards to a committee including representatives of manufacturers, the War Industries Board, and several Government departments. The specifications which were approved at that time were published in 1919 as an appendix to the Bureau's Circular ${ }^{2}$ on dry cells. Within a few years the need for revision became apparent and the Bureau was asked to call a conference of representatives of manufacturers, government departments, and some of the largest individual users of dry cells. This conference met. in December 1921 and agreed on a standardization program for sizes of cells and batteries, tests, and performance. New specifications were published in the second edition of the Bureau's Circular ${ }^{3}$ on dry cells, and following their adoption as a Government standard they were issued separately. ${ }^{4}$

In 1924 a conmittee consisting of representatives of the Government, battery manufacturers, and several large users of dry cells agreed on a standard system of nomenclature for dry cells and batteries. This has been used in subsequent revisions of the specifications. This committee initiated a movement for a more representative and permanent organization to deal with subsequent revisions of the dry-cell specifications with the result that the American Engineering Standards Committee (now the American Standards Association) authorized the formation of a sectional committee on dry cells under the sponsorship of the National Bureau of Standards. This committee has been active since its organization in 1926 and has prepared four revisions of the specifications, which became American Standards in $1928,{ }^{5} 1930,{ }^{6} 1937,{ }^{7}$ and $1941 .^{8}$

Close cooperation has been maintained between this sectional committee and the technical committee on dry cells reporting to the Federal Specifications Executive Committee with the result that Federal specifications issued in $1931^{9}$ and $1935^{10}$ have been concordant with the American standard specification, although differing in form. The

1 Trans, Am. Electrochem. Soc. 21, 275 (1912).

2 Cir. BS 79, 39 (1919).

3 Cir. BS 79, 2 d ed., 54 (1923).

1 Cir. BS 139 (1923); U. S. Government Standard Specification No. 58.

s Cir. BS 139, 2d ed. (1927); U. S. Government Master Specification No. 58a; ASA Standard C18-1928.

6 Cir. BS 390 (1930); ASA Standard C18-1930.

7 Cir. BS C414 (1937); ASA Standard C18-1937.

8 Cir. NBS C435; ASA Standard C18-1941.

- Federal Standard Stock Catalog, Specification Symbol W-B-101 (March 31, 1931).

10 Federal Standard Stock Catalog, Specification Symbol W-B-101a (May 7, 1935). 
1935 specification anticipated many of the changes incorporated in the 1937 American Standard, but did not include batteries intended primarily for use with hearing-aid devices. The Federal specification was again revised in $1942 .^{11}$

Periodic revision of the American Standard specifications becomes necessary as a result of changes in the art. New types and uses for batteries require the drafting of new specifications, and the improved performance of batteries justifies some increase in the requirements. The new specifications, therefore, reflect the advances made by manufacturers in their product. How great these advances have been during the past years may be judged from a few examples taken from a paper by Gillingham. ${ }^{12}$ His performance figures relate to the better brands available at the time, but are not necessarily confined to the product of any particular manufacturer.

The spontaneous shelf deterioration of dry cells of the ordinary no. 6 size for general purposes, occurring in 6 months, was reduced from 35 percent in 1901 to 25 percent in 1916 and to 7 percent in 1934 .

The useful output of dry cells, measured by their service life on various tests, described in the accompanying specifications, has been materially increased. Cells of the telephone type, made in 1910, gave 155 day : of service on the light intermittent test; those made in 1916 gave 165 days and the output was increased in 1926 to 230 days. About 1930, special grades of telephone cells became available giving 360 days, and some cells of 1934 reached 450 days.

In 1910, flashlight cells of the D size gave 260 minutes of service on the 4 -ohm intermittent test, but in 1934, cells of this type yielded as high as 750 minutes.

Industrial flashlight cells, intended for heavier service than the ordinary flashlight cells, appeared on the market about 1930, at which time they gave 250 minutes of service on the heavy-industrial test. Subsequent improvements were made rapidly with the result that 975 minutes of service on the same test were obtainable from cells made in 1935.

Radio $B$ batteries, which appeared about 1918, gave 377 hours on the 5,000 -ohm continuous test, but in 1926, batteries containing the same size of cell gave 1,000 hours, and this was increased to 1,500 hours of service from batteries made in 1934 .

Hearing-aid batteries ( $C D$ size) gave 18 hours of service in 1932 . In 1935, similar batteries gave 50 hours of service.

These examples illustrate improvements which are the result of organized research and development on the part of manufacturers and of standardized test procedures and specifications attained through cooperation of the groups represented on the sectional committee. To allow for manufacturing variations and to obtain adequate competition, it is necessary that the minimum required performance of the various types and sizes of cells included in the specifications be somewhat less than the maximum figures quoted above. The proportion of poorer brands on the market has decreased during the past few years. The result of all these factors has heen a considerable gain to the public at large.

\footnotetext{
11 Federal Standard Stock Catalog, Specification Symbol W-B-101b (1942). 12 Trans. Electrochem. Soc. 68, 159 (1935).
} 
The personnel of the sectional committee is as follows:

Organization represented

American Institute of Electrical Engineers.

American Society for Hard of Hearing.

ASA Sectional Committee on Accoustical Measurements and Terminology, Z24.

ASA Sectional Committee on Radio, C-16.

Association of American Railways, Signal Section.

Association of American Railways, Telephone \& Telegraph Section.

Association of Edison Illuminating Companies.

Bell Telephone Laboratories, Telephone Group, ASA.

Bright Star Battery Co.

Burgess Battery Co.

Electrochemical Society.

General Dry Batteries, Inc.

Independent Engineer.

Institute of Radio Engineers.

National Bureau of Standards.

\section{National Carbon Co.}

National Electric Wholesalers Association.

Navy Departiment.

Ray-O-Vac Co.

War Department.

Winchester Repeating Arms Co.
Name and business affliation
IV. B. Kouwenhoven, Johns Hopkins University, Baltimore, $M d$.

Douglas Macfarlan, M. D., Philadelphia, $\mathrm{Pa}$.

H. A. Carter, American Medical Association, Chicago, Ill.

F. T. Bowditch, National Carbon Co., Cleveland, Ohio.

A. B. Himes, Baltimore \& Ohio R. R., Baltimore, Md.

C. O. Ellis, Chicago, Rock Island \& Pacific Railway, Chicago, Ill.

H. C. Koenig, Electrical Testing Laboratories, New York City.

E. B. Wheeler, Bell Telephone Laboratories, New York, N. Y.

F. A. Keller, Bright Star Battery Co., Clifton, N. J.

H. W. Porth, Burgess Battery Co., Freeport, Ill.

Alternate: V. G. Reel.

C. C. Rose, Willard Storage Battery Co., Cleveland, Ohio.

C. G. Birdsall, General Dry Batteries, Inc., Cleveland, Ohio.

W. B. Kouwenhoven, Johns Hopkins University, Baltimore, $\mathrm{Md}$.

H. M. Turner, Yale University, New Haven, Conn.

J. P. Schrodt.

G. W. Vinal (chairman of committee), U. S. Department of Commerce, National Bureau of Standards, Washington, D. C.

C. A. Gillingham (secretary of committee), National Carbon Co., Cleveland, Ohio.

H. O. Smith, Hardware \& Supply Co., Akron, Ohio.

Officer in Charge, Standards Branch, Shipbuilding Division, Bureau of Ships, Navy Department, Washington, D. C.

R. E. Ramsay, Ray-O-Vac Co., Madison, Wis.

Maj. D. E. Washburn, Signal Corps, Washington, D. C.

Alternate: Hartwell F. Stallings.

John Martinez, Winchester Repeating Arms Co., New Haven, Conn. 



\section{AMERICAN STANDARD SPECIFICATION FOR DRY CELLS AND BATTERIES}

\section{American Standard C18-1941 \\ (Revision of $\mathrm{C} 18-1937$ )}

\section{CONTENTS}

Preface

History of the project

1. Definitions .........

2. Nomenclature $\ldots$

3. General classification of cells and batteries

4. Standard sizes of cells and batteries

5. Material and workmanship

6. Jackets

7. Marking

8. Zinc

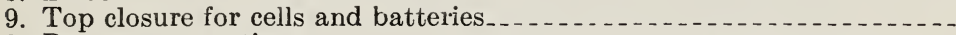

10. Battery connections

11. Terminals

12. Voltage tests

13. Capacity tests

14. Required performance-

1. Definitions.

1.1 Dry cells and batteries to be included under this specification shall fulfill the following requirements in addition to those in other paragraphs of this specification:

The cells shall be of sal-ammoniac type with depolarizer.

The cells shall have a nonspillable electrolyte.

2. Nomenclature.

2.1 For reference in this specification, the following system of nomenclature shall be used to designate sizes and types.

2.2 Cells listed and designated in table 1 are considered standard. This table shows nominal dimensions over the can for cylindrical cells,

TABLE 1.-Sizes of standard cylindrical cells

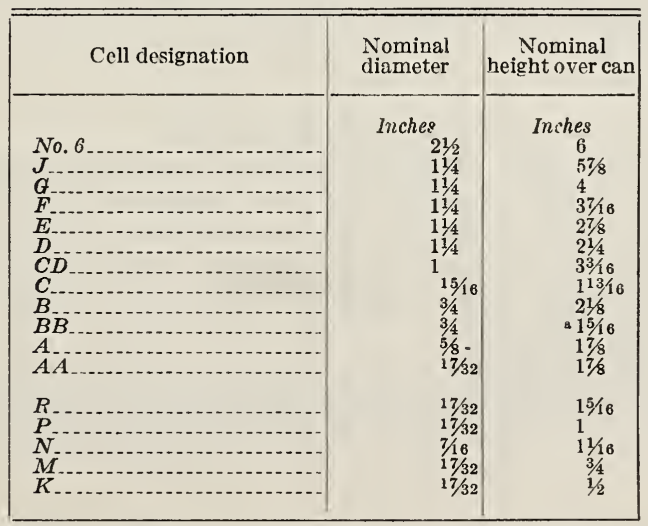

a This dimension applies to flashlight cells primarily for export. In $B$ batteries, cells approximately 3/16-inch higher are commonly used. 
but the designations may apply also to cylindrical cells of other dimensions and to cells of other shapes, which, when used in assembled batteries, correspond approximately to the standard size in volume or capacity rating. Such batteries shall be subject to standard dimension and performance requirements.

2.3 Assembled batteries are designated by a code similar to that of previous editions but simplified, and adaptable to present battery practice. The letters $G, H, V$, and $T$ formerly used to designate style have been discarded. New code designations are formulated as follows:

(1) The size of cell is indicated by a capital letter as shown in table 1. For the No. 6 cell, the number 6 is used in place of the letter.

(2) Preceding the cell letter is a numeral showing the number of cells (or $1 \frac{1 / 2}{2}$-volt groups) in series in the battery. If no numeral appears, it is to be understood that the battery is a $1 \frac{1}{2}$-volt battery.

(3) Following the cell-size letter is a numeral indicating the number of cells or groups of cells connected in parallel. If no numeral appears, it is to be understood that the battery consists of only a single series group.

(4) When a small letter $s$ or $d$ is used at the end of the code, it indicates either of two structural arrangements identical as to number and size of cells and electrical connections; $s$ indicating a single and $d$ a double-row arrangement.

3. General Classification of Cells and Batteries.

3.1 The following classes of dry cells and batteries are included in this specification:

(a) General-purpose No. 6 dry cells.

(b) Industrial No. 6 dry cells.

(c) Telephone cells, in No. $6, E$, and $D$ sizes.

(d) Assembled batteries of No. 6 cells.

(e) Group batteries of small cells, intended for No. 6 dry-cell applications.

(f) General-purpose flashlight cells.

(g) Industrial flashlight cells and batteries.

(h) Batteries for hearing aids.

(i) $B$ batteries.

(j) $A$ batteries.

(k) $C$ batteries.

4. Standard Sizes of Cells and Batteries.

4.1 No.6 Dry Cells. The dimensions for the zinc container of the cell, measured without the jacket, are: Diameter, $2 \frac{1}{2}$ inches; height, 6 inches. Deviations shall not exceed $1 / 16$ inch in diameter and $1 / 8$ inch in height, from the dimensions as given. The over-all dimensions, including the jacket and terminals, shall not exceed: Height, 6 $3 / 4$ inches; diameter, $2 \%$ inches.

4.2 Assembled Batteries of No. 6 Cells. Standard batteries of this class are shown with their required dimensions in table 2. 
TABLE 2.-Assembled batteries of No. 6 cells

\begin{tabular}{|c|c|c|c|c|c|c|}
\hline \multirow{2}{*}{ Battery designation } & \multirow{2}{*}{$\begin{array}{l}\text { Number } \\
\text { of cells in } \\
\text { series }\end{array}$} & \multirow{2}{*}{$\begin{array}{c}\text { Arranged } \\
\text { in }-\end{array}$} & \multirow{2}{*}{$\begin{array}{l}\text { Nominal } \\
\text { battery } \\
\text { voltage }\end{array}$} & \multicolumn{3}{|c|}{ Maximum dimensions } \\
\hline & & & & Length & Width & Height \\
\hline 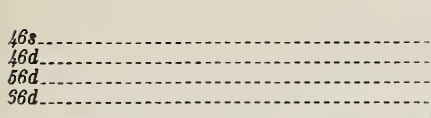 & $\begin{array}{l}4 \\
4 \\
5 \\
6\end{array}$ & $\begin{array}{l}1 \text { row } \\
2 \text { rows...- } \\
2 \text { rows } \\
2 \text { rows..- }\end{array}$ & $\begin{array}{c}\text { Volts } \\
6 \\
6 \\
71 / 2 \\
9\end{array}$ & $\begin{array}{c}\text { Inches } \\
10^{5} / 8 \\
53.8 \\
8 \\
8\end{array}$ & $\begin{array}{r}\text { Inches } \\
23 / 4 \\
538 \\
53 / 8 \\
536\end{array}$ & $\begin{array}{l}\text { Inches } \\
71 / 2 \\
71 / 2 \\
71 / 2 \\
71 / 2\end{array}$ \\
\hline
\end{tabular}

4.3 Group Batteries of Small Cells (for No. 6 cell applications). Cells contained in these batteries may be of various sizes as preferred by the manufacturer. Batteries shall comply with the dimension requirements of table 3 .

Table 3.-Group batteries of small cells (for No. 6 cell applications)

\begin{tabular}{|c|c|c|c|}
\hline \multirow{2}{*}{$\begin{array}{l}\text { Nominal } \\
\text { battery } \\
\text { voltage }\end{array}$} & \multicolumn{3}{|c|}{ Maximum dimensions } \\
\hline & Length & Width & $\begin{array}{c}\text { Orer-all } \\
\text { height }\end{array}$ \\
\hline $\begin{array}{l}\text { Volts } \\
11 / 2 \\
3 \\
41 / 2 \\
6 \\
71 / 2 \\
9\end{array}$ & $\begin{array}{l}\text { Inches } \\
2^{5} / 8 \\
4 \\
4 \\
2^{3} / 4 \\
4 \\
4\end{array}$ & $\begin{array}{l}\text { Inches } \\
25 \% 3 \\
23 / 4 \\
4 \\
81 / 4 \\
75 / 16 \\
81 / 4\end{array}$ & $\begin{array}{c}\text { Inches } \\
6^{1 / 4} \\
61 / 4 \\
61 / 4 \\
6^{3} / 8 \\
6^{3 / 3} \\
6^{3 / 3}\end{array}$ \\
\hline
\end{tabular}

4.4 Flashlight Cells and Batteries. Those which are considered standard are listed in table 4 and shall comply with the dimensions shown therein.

TABLE 4.-Flashlight cells and batteries

\begin{tabular}{|c|c|c|c|c|}
\hline \multirow{2}{*}{ Cell or battery designation } & \multicolumn{2}{|c|}{$\underset{\text { sions }}{\text { Maximum dimen- }}$} & \multicolumn{2}{|c|}{$\underset{\text { sions }}{\text { Minimum dimen- }}$} \\
\hline & Diameter & Height & Diameter & Height \\
\hline \multicolumn{5}{|c|}{ UNIT CELLS a } \\
\hline $\begin{array}{l}D \\
C \\
B B \\
A A\end{array}$ & $\begin{array}{c}\text { Inches } \\
111 / 32 \\
111 / 32 \\
27 / 32 \\
1932\end{array}$ & $\begin{array}{rl}\text { Inches } \\
213 / 32 \\
131 / 32 \\
1532 \\
131 / 32 \\
1 & 31 / 32\end{array}$ & $\begin{array}{c}\text { Inches } \\
19 / 32 \\
31 / 32 \\
25 / 32 \\
17 / 32\end{array}$ & $\begin{array}{r}\text { Inches } \\
25 / 16 \\
17 / 8 \\
13 / 8 \\
129 / 32\end{array}$ \\
\hline \multicolumn{5}{|c|}{ I.ANTERN BATTERT } \\
\hline $4 F_{-} \ldots$ & b3 $3 / 8$ & •4 & & $313 / 16$ \\
\hline
\end{tabular}

3 Cells may be supplied as tubular batteries as follows if required: $2 D, s D, 2 C, 2 B B, 2 A A$

b Maximum diagonal. This battery must pass through a circle $33 / 8$ inches in diameter.

c Height over body, exclusive of terminals. 
4.5 Batteries for Hearing Aids. These batteries are of several groups, according to the type of instrument for which they are intended, and are so arranged in table 5 . Such batteries shall comply with dimensions listed in the table. Codes referring to the various batteries are described in section 2.3 .

TABLE 5.-Batteries for hearing aids

\begin{tabular}{|c|c|c|c|c|c|c|}
\hline \multirow{2}{*}{ Classification } & \multirow{2}{*}{$\begin{array}{c}\text { Battcry } \\
\text { designa- } \\
\text { tion }\end{array}$} & \multirow{2}{*}{$\begin{array}{c}\text { Recom- } \\
\text { mended } \\
\text { terminal } \\
\text { arrange- } \\
\text { ment }\end{array}$} & \multirow{2}{*}{$\begin{array}{c}\text { Battery } \\
\text { voltage } \\
\text { (nominal) }\end{array}$} & \multicolumn{3}{|c|}{ Maximum dimensions } \\
\hline & & & & Length & Width & $\begin{array}{l}\text { Body } \\
\text { height }\end{array}$ \\
\hline For "carbon" type instruments... & $\begin{array}{l}S B \\
3 C \\
2 C D \\
3 C D\end{array}$ & $\begin{array}{l}\text { XX } \\
\text { XX } \\
X X \\
\text { XX }\end{array}$ & $\begin{array}{l}\text { Vo.ts } \\
\quad 4.5 \\
\quad 4.5 \\
\quad 3 . \\
\quad 4.5\end{array}$ & $\begin{array}{c}\text { Inches } \\
2112 \\
3116 \\
2316 \\
314\end{array}$ & $\begin{array}{c}\text { Inches } \\
7,8 \\
11,16 \\
11 / 8 \\
11 / 8\end{array}$ & $\begin{array}{c}\text { Inches } \\
215 / 10 \\
256 \\
41 \% 8 \\
41 \% 8\end{array}$ \\
\hline$B$ batteries for vacuum-tube instruments. & $\begin{array}{l}(\mathrm{s}) \\
(\mathrm{s}) \\
(\mathrm{a}) \\
(\mathrm{s})\end{array}$ & 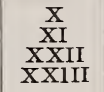 & $\begin{array}{l}45 \\
30 \\
22.5\end{array}$ & $\begin{array}{l}(\mathrm{a}) \\
(\mathrm{a}) \\
(\mathrm{a}) \\
(\mathrm{a})\end{array}$ & $\begin{array}{l}(\mathrm{a}) \\
(\mathrm{a}) \\
(\mathrm{a}) \\
(\mathrm{a})\end{array}$ & $\begin{array}{l}\text { (a) } \\
(\mathrm{a}) \\
(\mathrm{a}) \\
(\mathrm{a})\end{array}$ \\
\hline$A$ cells for vacuum-tube instruments....- & $\left\{\begin{array}{l}D \\
C\end{array}\right.$ & & $\begin{array}{l}1.5 \\
1.5\end{array}$ & 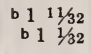 & & $\begin{array}{l}0.213 / 32 \\
0131 / 32\end{array}$ \\
\hline
\end{tabular}

a Battcry types and dimensions of $B$ batteries not yet standarized. Expected standards for terminals and voltages are shown in the appropriate columns.

b Diameter of cylindrical cells with jackets.

- Over-all hcight.

4.6 $B$ Batteries. These batteries are for vacuum-tube platecurrent supply, and are usually furnished in series-assembled units of $22 \frac{1}{2}$ volts and multiples thereof, table 6 .

TABLE 6.-B batteries

\begin{tabular}{|c|c|c|c|c|c|}
\hline \multirow[b]{2}{*}{ Battcry designation } & \multirow{2}{*}{$\begin{array}{l}\text { Battery } \\
\text { voltage } \\
\text { (nominal) }\end{array}$} & \multirow{2}{*}{$\begin{array}{l}\text { Terminal } \\
\text { arrange- } \\
\text { ment }\end{array}$} & \multicolumn{3}{|c|}{ Maximum dimensions } \\
\hline & & & Length & Width & $\underset{\text { hcight a }}{\text { Body }}$ \\
\hline $\begin{array}{l}\text { SOK } \\
\text { SON } \\
\text { SON } \\
\text { SOA } \\
\text { SOA } \\
15 A \\
\text { SOBB } \\
\text { SOB } \\
15 B \\
\text { SOD } \\
\text { SOF } \\
\text { SOG }\end{array}$ & $\begin{array}{l}\text { Volts } \\
45 \\
45 \\
67.5 \\
45 \\
45 \\
45 \\
22.5 \\
45 \\
45 \\
22.5 \\
45 \\
45 \\
45\end{array}$ & $\begin{array}{l}\text { III } \\
\text { X } \\
X \\
I \\
\text { II } \\
\text { II } \\
\text { II } \\
\text { II } \\
\text { VII } \\
\text { I } \\
\text { I } \\
\text { I }\end{array}$ & 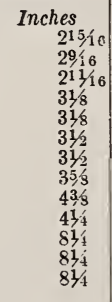 & 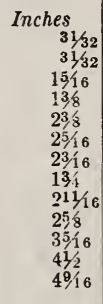 & $\begin{array}{l}\text { Inches } \\
37,8 \\
35,8 \\
35,8 \\
43 / 16 \\
4316 \\
458 \\
211 / 16 \\
51 / 2 \\
51 / 2 \\
3 \\
73 / 8 \\
73 / 8 \\
738\end{array}$ \\
\hline $60 D \cdot F 18^{t} \ldots$ & 90 & $1 \mathrm{X}$ & 16 & $41 / 2$ & $67 / 8$ \\
\hline
\end{tabular}

aUsers must provide clearance above battery for adaptor or other terminals. Ordinarily $3 / 4$-inch is sufficient.

bThis is a combination $A-B$ nack. Voltage shown in table 6 is for $B$ section. The A section voltage is 1.5 nominal, and cell arrangements other than $F 18$ may be used as indicated for the F18 battery in table 7 .

4.7 A Batteries. Standard types of $A$ batteries are listed with dimension requirements in table 7. For descriptive code, see section 2.3 of this specification.

$A$ batteries are designed to supply filament current for vacuum tubes, especially in portable receivers. 
TABLE 7.- $A$ batteries

\begin{tabular}{|c|c|c|c|c|c|}
\hline \multirow[b]{2}{*}{ Battery designation } & \multirow{2}{*}{$\begin{array}{c}\text { Battery } \\
\text { roltage } \\
\text { (nominal) }\end{array}$} & \multirow{2}{*}{$\begin{array}{l}\text { Terminal } \\
\text { arrange- } \\
\text { ment }\end{array}$} & \multicolumn{3}{|c|}{ Maximun dimensions } \\
\hline & & & Length & Width & $\begin{array}{l}\text { Body } \\
\text { height }\end{array}$ \\
\hline 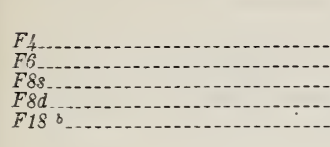 & $\begin{aligned} \text { Volts } \\
1.5 \\
1.5 \\
1.5 \\
1.5 \\
1.5\end{aligned}$ & $\begin{array}{l}\text { IV } \\
\text { IV } \\
\text { IV } \\
\text { IV } \\
\text { IV }\end{array}$ & $\begin{array}{r}\text { Inches } \\
2^{5}, 8 \\
378 \\
378 \\
378 \\
378 \\
73 / 4\end{array}$ & $\begin{array}{c}\text { Inches } \\
2^{5 / 8} \\
2^{11} 1 / 16 \\
17 / 16 \\
2^{33} 4 \\
2^{15} 16\end{array}$ & $\begin{array}{r}\text { Inches } \\
41,8 \\
41 / 8 \\
10^{3} / 4 \\
51 / 2 \\
71,8\end{array}$ \\
\hline$s G$ & 4. 5 & $\mathrm{~V}$ & 4 & $13 / 3$ & 434 \\
\hline $\begin{array}{l}4 F 2 s \\
4 F 2 d\end{array}$ & $\begin{array}{l}6 \\
6\end{array}$ & $\begin{array}{l}\text { VI } \\
\text { VI }\end{array}$ & $\begin{array}{l}315 / 16 \\
3^{15}, 16\end{array}$ & $\begin{array}{l}17 / 16 \\
23 / 4\end{array}$ & $\begin{array}{r}10^{3} / 4 \\
51 / 2\end{array}$ \\
\hline
\end{tabular}

a Terminals located on top of battery.

b Other batteries for similar service include $F 20, G 15, G 16, G 18, G 19, J 12$. Alternate maximum dimensions may be $4^{5} / 8$ by $37 / 8$ by $7^{3}, 4$ inches.

4.8 $C$ Batteries. Standard types are listed with dimensions in table 8. They are intended to supply bias voltage to vacuum tubes.

TABLE 8.-C batteries

\begin{tabular}{|c|c|c|c|c|c|}
\hline \multirow{2}{*}{ Battery designation } & \multirow{2}{*}{$\begin{array}{c}\text { Battery } \\
\text { voltage } \\
\text { (nominal) }\end{array}$} & \multirow{2}{*}{ Terminal arrangement } & \multicolumn{3}{|c|}{ Maximum dimensions } \\
\hline & & & Length & Width & $\begin{array}{l}\text { Body } \\
\text { height }\end{array}$ \\
\hline $\begin{array}{l}3 B^{a} \\
5 B \\
3 D \\
3 D\end{array}$ & $\begin{array}{r}\text { Volts } \\
4.5 \\
7.5 \\
22.5 \\
4.5\end{array}$ & $\begin{array}{l}\text { Screw or spring clip.... } \\
\text { As required } \\
\text { VII } \\
\text { VIII }\end{array}$ & \begin{tabular}{c|} 
Inches \\
$21 / 2$ \\
$41 / 4$ \\
$41 / 4$ \\
4116
\end{tabular} & $\begin{array}{c}\text { Inches } \\
7 / 8 \\
15 / 16 \\
258 \\
11 / 2\end{array}$ & Inches \\
\hline
\end{tabular}

a Battery $3 B$ is also furnished with plug-in terminal type VIII with dimensions $41 / 16$ by $1 \frac{1}{2}$ by 3 inches.

\section{Material and Workmanship.}

5.1 The material and workmanship shall be first class in every particular. Cells or batteries having any of the following defects shall be considered as not complying with this part of the specification: Loose terminal's, spring clips or plug-in terminals which do not make and maintain positive connections to the external circuit, high or low carbons, corrosion of metal cap on carbon rods, carbon rods off center, loose or cracked seals, leaking or distorted zinc containers. Cells and assembled batteries shall be free from deformation and leakage during their useful life under specified test conditions.

\section{JACKETS.}

6.1 Single No. 6 dry cells and flashlight unit cells shall be enclosed in close-fitting jackets usually of news, chip-, or straw-board. For special purposes jackets may be treated when so specified, with paraffin or other waterproofing material. Waterproofing material shall not cover the cell terminals.

When metal-clad jackets are provided on unit cells, they shall be insulated from both terminals of the cell, and shall be covered outside with insulating material which is adherent and resistant to penetration by exposed metal switch parts of flashlights or other equipment in which the cells are used. 


\section{MARKING.}

7.1 On the outside of the jackets of individual cells and outside of batteries shall be printed the following information:

The trade name of the cell or battery.

The name of the manufacturer or supplier, or such trade-mark as will identify him.

Number or other designation of size.

The date of manufacture, or the expiration of a guaranty period, indicated as such. (Option: This may be shown on the zinc container, provided jacket is removable.)

8. ZiNc.

8.1 The anode shall be made from smooth zinc, free from flaws, blisters, and cracks.

\section{Top Closure for Cells and Batteries.}

9.1 Sealing compound used for closing cells and batteries at the top shall be an insulating compound which will not flow at a temperature of $45^{\circ} \mathrm{C}\left(113^{\circ} \mathrm{F}\right)$ during a static test in which the sealed surface is held vertical for a period of 24 hours.

9.2 Metal or composition covers for tops of cells may be used in lieu of sealing compound, provided such covers and accessory parts shall not become adversely affected during the useful life of the cell by leakage, corrosion, or deformation. Metal covers shall be insulated from at least one electrode.

9.3 Metal boxes and covers for assembled batteries shall in every case be insulated from the cells comprising the battery. The top closing means may be metal, fiber, paperboard, or sealing compound. 10. Battery Connections.

10.1 In all assembled batteries, electrical connections between cells and between cells and terminals shall be secure and permanent.

10.2 All soldered connections shall be made, using a noncorrosive and nonconducting soldering flux to avoid current leakage across insulators and corrosion of connections and terminals.

10.3 Welded connections may be used in lieu of soldered connections, provided they are equally permanent.

\section{Terminals.}

11.1 No. 6 Cells. The terminals shall be of the knurled-nut-andscrew type (thread 8-32), or spring clips if specified. They shall be of brass or equally suitable metal. The terminals shall not be obstructed by the cardboard jacket, solder, or protruding material of the seal.

11.2 Assembled Batteries of No. 6 Cells (table 2). The terminals shall be brought through the top of case or sealing material to binding posts or spring clips. The polarity of the terminals shall be marked.

11.3 Group Batteries of Small Cells (table 3). These batteries shall have terminals same as No. 6 dry cells.

11.4 Flashlight Cells (table 4). The metal cap on the carbon rod, and the zinc bottom, of flashlight cells or flashlight batteries, serve as the terminals, and they shall be clean to insure good electrical contact. 
11.5 Lantern Batteries (table 4). The terminals shall be of spring brass or bronze, brought through the cover at the top. The point of contact of one terminal shall be at the center and that of the other 1 inch from it.

11.6 B Batteries (table 6). These batteries shall have connections between cells as provided in section 10 above, except where pressure contact between adjacent cells makes wired connections unnecessary.

Terminal designations in roman numerals refer to "plug-in" sockets shown in figure 1, or to snap-fastener terminals shown in figure 2. Terminal arrangements called for in table 6 shall be standard. The "plug-in" terminals shall consist of a receptacle with the appropriate number of sockets conforming in arrangement with the layouts in figure 1. An adaptor to fit the receptacle and having spring terminals shall be made available by the manufacturer. Adaptor shall make good electrical contact in the socket.

On batteries not equipped with "plug-in" sockets, spring-clip or screw terminals (8-32) with knurled nuts shall ordinarily be provided.

Under special conditions, wire terminals may be required. They shall be flexible tinned copper conductor equivalent to No. 18 (AWG), rubber-insulated and covered with single cotton braid. The positive terminal shall have a red braid and the negative terminal a black braid. Wire leads shall be 6 inches long. If batteries are waterproofed, the waterproofing material shall not be allowed to cover the terminals.

11.7 A Batteries (table 7). These shall have "plug-in" terminals as called for in the table and conforming to layout in figure 1. Cells shall be joined electrically according to methods specified for $B$ batteries in 11.6.

11.8 $C$ Batteries (table 8). The terminals shall be as described in section 11.6 for $B$ batteries. If of the "plug-in" type, they shall conform to figure 1 .

11.9 Hearing-aid Batteries. Cell connections in hearing-aid batteries shall be made as specified for $B$ batteries in 11.6.

Terminals of hearing-aid batteries of the types specified in table 5 , and described in figures 2,3 , and 4 are recommended as standard practice. Terminals must be such that good contact is maintained at all times with the instrument terminals in order to avoid noise and unsatisfactory transmission and shall be of such design that reversal of polarity of instrument terminals is impossible.

\section{Voltage Tests.}

12.1 The voltage of individual cells shall be not less than the values shown in table 9 when measured with a voltmeter having a resistance of not less than $100 \mathrm{ohms}$ per volt and having not less than 50 divisions of its scale per volt.

12.2 The voltage of batteries of two or more cells shall be not less than the product of the required minimun voltage per cell by the number of cells (or 1/2-volt groups) in series in the battery. The voltage of cells and batteries other than $B$ and $C$ batteries shall be measured with a voltmeter having a resistance of not less than 100 ohms per volt and a scale having at least 100 divisions. The voltage of radio batteries for the plate $(B)$ circuit and for the grid $(C)$ circuit shall be measured with a voltmeter having not less than 1,000 ohms resistance per volt and a scale having not less than 100 divisions. 
12.3 Voltage tests are intended to apply to fresh cells or betteries and shall be made within 30 days of receipt of samples by the testing agency.

TABLE 9.-Minimum cell voltage

\begin{tabular}{|c|c|}
\hline Cell size & Minimum voltage \\
\hline Smaller than $B B$ & $\begin{array}{ll}V_{1.47} & \\
& \end{array}$ \\
\hline Larger than $C$ & $\begin{array}{l}1.48 \\
1.49 \\
1.50\end{array}$ \\
\hline
\end{tabular}

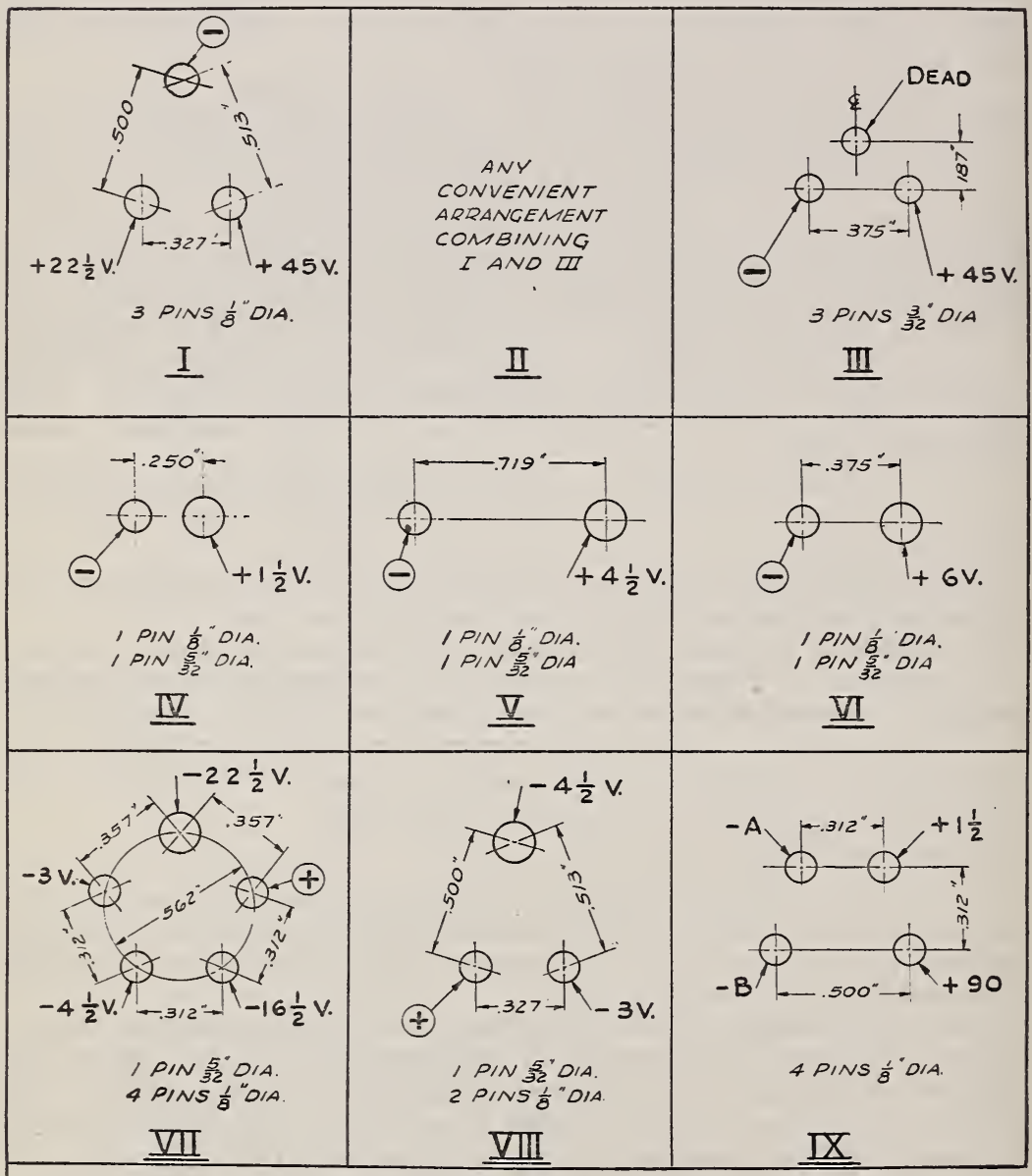

FIGURE 1. 

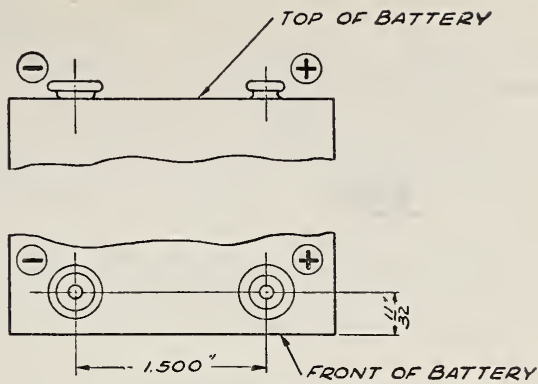

- TERMINAL - SOCKET-PART NO.12208

(4 TERMINAL - STUD - PART NO.12302 FASTENERS AS SUPDLIED BY UNITED-CARR FASTENER CORP, OR EQUIVALENT

$\underline{X}$

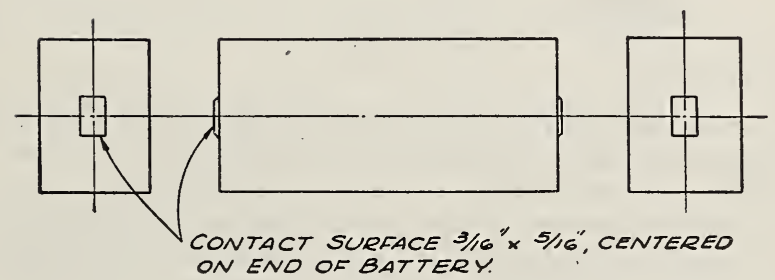

$\underline{\text { XI }}$

Figure 2.

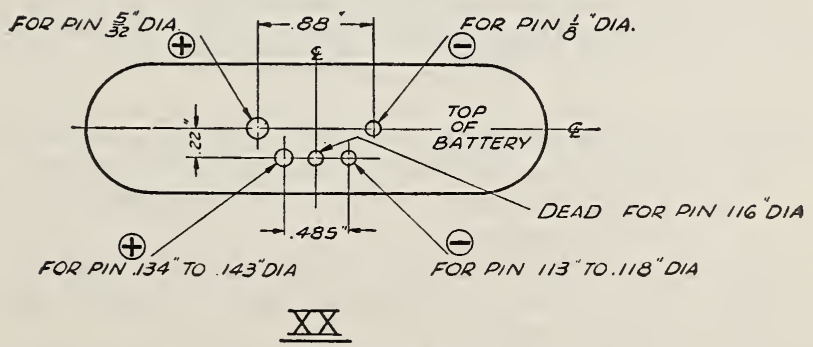

Figure 3. 


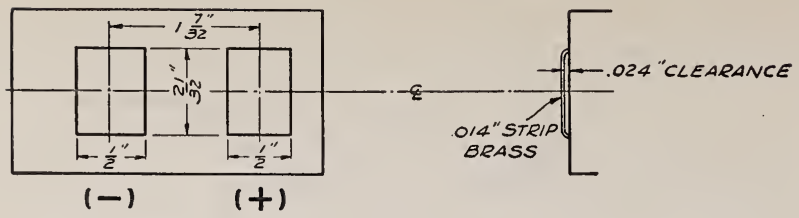

XXII

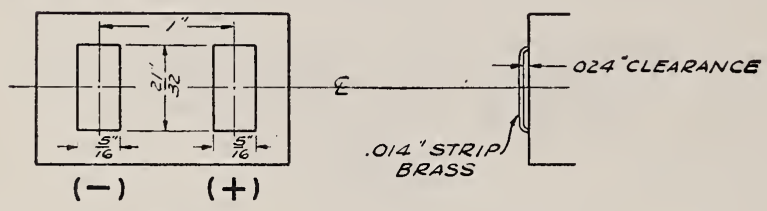

XXIII

Figure 4.

\section{Capacity Tests.}

13.1 The size and kind of dry cell or battery and the conditions of service determine the kind of test to be applied. The test which best represents any particular service is that which most nearly duplicates the rate-of-energy output of the battery when in actual use. Intermittent tests are preferred to continuous tests and shall be used wherever possible, since there is no direct relation between the results of continuous tests and intermittent tests of longer duration.

"Initial" tests intended to show the condition of fresh batteries shall be started within 30 days of the receipt of the batteries by the testing agency. All tests not otherwise designated shall be understood to be "initial" tests.

"Delayed" service tests are intended to measure the keeping quality of cells and batteries before use. Cells and batteries for delayed test shall have been stored on open circuit at an even temperature of $21^{\circ} \mathrm{C}\left(70^{\circ} \mathrm{F}\right)$ for the period of time specified before being subjected to the procedure for the test specified in the tables of requirements under 14 .

The standard temperature for tests is $21^{\circ} \mathrm{C}\left(70^{\circ} \mathrm{F}\right)$, unless otherwise specified. Deviations from this temperature shall be stated.

The resistance of the discharge circuit shall be maintained within 0.5 percent of its nominal value.

In making capacity tests on $B$ and $C$ batteries, readings of working voltage shall be taken with a voltmeter having a resistance of not less than 1,000 ohms per volt.

To determine compliance with this specification, those tests shall be applied for which requirement figures are given in tables 10, 11, $12,13,14,15$, and 16 .

In the tests described below the frequency of readings specified for each test relates to the larger and more commonly used sizes of cells 
and batteries. When the smaller sizes are tested, more frequent readings are required.

\subsection{Description of Tests.}

(a) Light intermittent test. Three cells connected in series shall be discharged through a resistance of $20 \mathrm{ohms}$ for 10 periods of 4 minutes each, beginning at hourly intervals during 6 days per week. On the remaining day, every other discharge period shall be omitted. (There are 65 such discharge periods per week, or a total weekly service of 260 minutes.)

The following readings shall be taken: Initial open-circuit voltage of the battery; initial closed-circuit voltage of the battery; closedcircuit voltage at the end of the tenth discharge of each succeeding fourteenth day.

The test shall be continued until the closed-circuit voltage of the battery falls below 2.8 volts. The service shall be reported as the total number of days on test to 2.8 volts.

(b) FIFTY-OHM TELEPHONE TEST. This test shall be conducted exactly as called for in section (a) above, except that the three cells shall be discharged through 50 instead of $20 \mathrm{ohms}$, and the cut off voltage shall be 3.25 instead of 2.8 volts.

(c) HEAVy INTERMitTENT TEST. The battery shall be discharged through a resistance of $2 \frac{2}{3} \mathrm{ohms}$ for each cell in series for two periods of 1 hour each daily. The interval between daily discharge periods shall be not less than 6 hours.

The following readings shall be taken: Initial open-circuit voltage of the battery; initial closed-circuit voltage of the battery; closed-circuit voltage every alternate working day thereafter at the end of the second discharge period of the day.

The test shall be continued until the closed-circuit voltage of the battery falls below 0.85 volt per cell. The service shall be reported as the total number of hours of actual discharge to 0.85 volt per cell.

(d) HOUSEHOLD-FLASHLight INTERMitTENT TEST. Each cell shall be discharged through a resistance of $4 \mathrm{ohms}$ for 5 -minute periods, at 24-hour intervals.

The following readings shall be taken: Initial open-circuit voltage of the cell; initial closed-circuit voltage of the cell; closed-circuit voltage of the cell at the end of a discharge period twice each week thereafter.

The test shall be continued until the closed-circuit voltage of the cell falls below 0.75 volt. The service shall be reported as the total number of minutes of actual discharge to 0.75 volt.

(e) Light-INDUSTRIAl FLASHLight test. Each cell shall be discharged through a resistance of $4 \mathrm{ohms}$ for 4 -minute periods beginning at hourly intervals for 8 consecutive hours every day, with 16-hour rest periods intervening. (There are eight such discharge periods each day or a total daily discharge of 32 minutes.)

The following readings shall be taken: Initial open-circuit voltage of the cell; initial closed-circuit voltage of the cell; closed-circuit voltage of the cell daily at the end of the last discharge period.

The test shall be continued until the closed-circuit voltage of the cell falls below 0.90 volt. The service shall be reported as the total number of minutes of actual discharge to 0.90 volt. 
(f) Heavy-industrial Flashlight test. Each cell shall be discharged through a resistance of $4 \mathrm{ohms}$ for 4 -minute periods, beginning at 15-minute intervals, for 8 consecutive hours every day, with 16-hour rest periods intervening. (There are 32 such discharge periods each day, or a total daily discharge of 128 minutes.)

The following readings shall be taken: Initial open-circuit voltage of the cell; initial closed-circuit voltage of the cell; closed-circuit voltage of the cell at the end of the sixteenth and thirty-second discharge periods daily.

The test shall be continued until the closed-circuit voltage of the cell falls below 0.90 volt. The service shall be reported as the total number of minutes of actual discharge to 0.90 volt.

(g) RAILROAD-LANTERN BATTERY TEST. The battery shall be discharged every day during eight periods of 30 minutes each, beginning at intervals of 1 hour for 8 consecutive hours, through a resistance of 8 ohms for each cell in series in the battery.

The following readings shall be taken: Initial open-circuit voltage of the battery; initial closed-circuit voltage of the battery; closedcircuit voltage of the battery daily thereafter at the end of the last period of discharge for the day.

The test shall be continued until the closed-circuit voltage of the batter'y falls below 0.90 volt per cell. The service shall be reported as the total number of hours of actual discharge to 0.90 volt per cell.

(h) REGULAR HEARING-AID TEST. The battery shall be discharged through a resistance of $15 \mathrm{ohms}$ for each cell in series in the battery, for one continuous 6-hour period each day, at a temperature of $70^{\circ} \mathrm{F}$ $\left(21^{\circ} \mathrm{C}\right)$.

The following readings shall be taken: Initial open-circuit voltage; initial closed-circuit roltage; closed-circuit voltage at the end of each 6-hour period of discharge, with readings during the discharge period if necessary to determine accurately the end of the test.

The test shall be continued until the closed-circuit voltage falls below 1.0 volt per cell. The service shall be reported as the total number of hours of actual discharge to 1.0 volt per cell.

(i) HEARING-AID $B$ BATTERy TEST. Each 221/2-volt unit of the battery shall be discharged through a resistance of 22,500 ohms during a continuous 6-hour period each day.

The following readings shall be taken: Initial open-circuit voltage; initial closed-circuit voltage; closed-circuit voltage at the end of each discharge period.

The test shall be continued until closed-circuit voltage falls below 15 volts. The service shall be reported as the total number of hours of actual discharge to 15 volts.

(j) 5,000-oHM INTERMITTENT TEsT. Each 22\%1/2-volt (nominal voltage) battery unit shall be discharged through a resistance of $5,000 \mathrm{ohms}$ during a continuous period of 4 hours daily, the intervals between successive discharge periods being not less than 16 hours.

The following readings shall be taken: Initial open-circuit voltage of the battery; initial closed-circuit voltage of the battery; closedcircuit voltage at the end of alternate discharge periods.

The test shall be continued until the closed-circuit voltage falls below 15 volts. The service shall be reported as the total number of hours of actual discharge to 15 volts. 
(k) 2,500-OHM INTERMittent test. This test shall be as specified in paragraph (j) of 13.2 above, with the exception that $2,500 \mathrm{ohms}$ shall be used in place of $5,000 \mathrm{ohms}$.

(1) 1,250-OHM INTERMitTENT TEST. This test shall be as specified in paragraph (j) of 13.2 above, with the exception that $1,250 \mathrm{ohms}$ shall be used in place of $5,000 \mathrm{ohms}$.

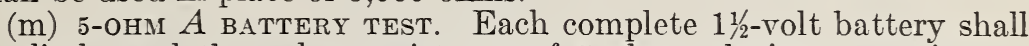
be discharged through a resistance of $5 \mathrm{ohms}$, during a continuous period of 4 hours daily.

The following readings shall be taken: Initial open-circuit voltage; initial closed-circuit voltage; closed-circuit roltage at the end of alternate discharge periods.

The test shall be continued until the closed-circuit voltage falls below 1.0 volt. The service shall be reported as the total number of hours of actual discharge to 1.1 and 1.0 volts.

(n) 25-OH. $A$ Battery test. Each complete battery shall be discharged through a resistance of $25 \mathrm{ohms}$ for each $1 \frac{1}{2}$ volts of nominal battery voltage during a continuous period of 4 hours daily.

The following readings shall be taken: Initial open-circuit voltage; initial closed-circuit voltage; closed-circuit voltage at the end of alternate discharge periods.

The test shall be continued until the closed-circuit voltage falls below 1.0 volt per cell in series in the battery. The service shall be reported as the total number of hours of actual discharge to 1.1 and 1.0 volts per cell.

13.3 C Battery Tests. The $C$ batteries shall be stored on opencircuit at an even temperature of approximately $21^{\circ} \mathrm{C}\left(70^{\circ} \mathrm{F}\right)$, and voltage readings shall be taken at intervals of not exceeding 1 month.

The test shall be continued until the open-circuit voltage falls below 1.45 volts per cell. The service shall be reported as the number of months to 1.45 volts per cell.

\section{Required Performance.}

Batteries and cells of the various types and sizes shall comply with the performance requirements listed in tables 10 to 16 , inclusive, as indicated below:

(a) No. 6 dry cells and telephone cells _._. . . . . . . Table 10.

(b) Group batteries of small cells intended as equivalent to No. 6 cells shall meet the requirements shown for the corresponding type of No. 6 cells in ....... Table 10.

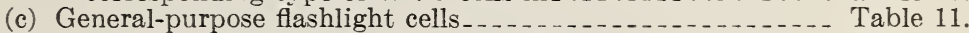

(d) Industrial flashlight cells and batteries............... Table 12.

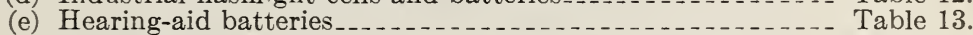

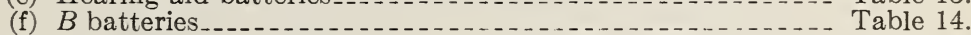

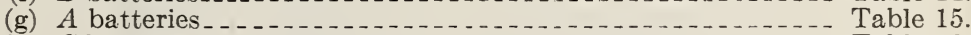

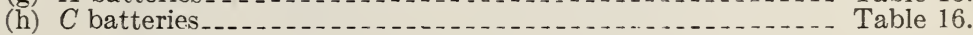


TABLE 10.-No. 6 dry cells and cells for telephone applications

\begin{tabular}{|c|c|c|c|c|}
\hline \multirow{2}{*}{ Sizes and types } & \multirow{2}{*}{$\begin{array}{l}\text { Light in- } \\
\text { termittent } \\
\text { test }\end{array}$} & \multirow{2}{*}{$\begin{array}{l}\text { 50-ohm } \\
\text { telephone } \\
\text { test }\end{array}$} & \multicolumn{2}{|c|}{$\begin{array}{c}\text { Heary intermittent } \\
\text { test }\end{array}$} \\
\hline & & & Initial & $\begin{array}{l}6 \text { months } \\
\text { delayed }\end{array}$ \\
\hline $\begin{array}{l}\text { No. } 6 \text { general-purpose a } \\
\text { No. } 6 \text { industrial b } \\
\text { No. } 6 \text { "Special" telephone } 0 \\
\text { No. } 6 \text { "Regular" telephone } \\
\text { Size } E \text {. telephone } \\
\text { Size } D \text { telephone }\end{array}$ & $\begin{array}{r}\text { Days } \\
200 \\
275 \\
325 \\
250 \\
45 \\
30\end{array}$ & $\begin{array}{r}\text { Days } \\
500 \\
625 \\
470 \\
80 \\
60\end{array}$ & $\begin{array}{r}\text { Hours } \\
70 \\
100 \\
0.0 \\
\end{array}$ & 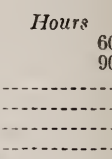 \\
\hline
\end{tabular}

a Cells not otherwise specifically marked or represented by the manufacturer shall be considered as general-purpose cells and tested according to the requirements thereof.

${ }_{b}$ This type of cell is intended for applications where highly efficient performance is required on both heavy and light scrvices.

c No requirements are shown for telephone cells on heavy intermittent test as these types are not usilally intended for heary service.

TABLE 11.-General-purpose flashlight cells

\begin{tabular}{|c|c|c|c|}
\hline \multirow[b]{2}{*}{ Cell designation } & \multirow{2}{*}{$\begin{array}{l}\text { Light-indus- } \\
\text { trial test a }\end{array}$} & \multicolumn{2}{|c|}{ Household intermittent test } \\
\hline & & Initial & $\begin{array}{c}6 \text { months de- } \\
\text { layed }\end{array}$ \\
\hline$C_{A} A^{D}$ & Minutes & $\begin{array}{r}\text { Minutes } \\
600 \\
300 \\
65\end{array}$ & $\begin{array}{r}\text { Minutes } \\
550 \\
250 \\
50\end{array}$ \\
\hline
\end{tabular}

a The light-industrial test has been added for general-purpose $D$ size cells to provide a test of greater severity and shorter duration than the usual household intermittent test.

TABLE 12.-Industrial flashlight cells and batteries

\begin{tabular}{|c|c|c|c|c|c|c|}
\hline \multirow{2}{*}{ Type designation } & \multicolumn{2}{|c|}{$\begin{array}{c}\text { Heavy-industrial } \\
\text { test }\end{array}$} & \multicolumn{2}{|c|}{$\underset{\text { test }}{\text { Light-industrial }}$} & \multicolumn{2}{|c|}{$\begin{array}{c}\text { Railroad-lantern } \\
\text { test }\end{array}$} \\
\hline & Initial & $\begin{array}{c}3 \text { months } \\
\text { delayed }\end{array}$ & Initial & $\begin{array}{l}3 \text { months } \\
\text { delayed }\end{array}$ & Initial & $\begin{array}{l}6 \text { months } \\
\text { delayed }\end{array}$ \\
\hline $\begin{array}{l}D \text {, heavy-industrial } \\
D \text {, light-industrial } . . . . \\
4 F \text {, railread -lantern }\end{array}$ & $\begin{array}{r}\text { Minutes } \\
750\end{array}$ & $\begin{array}{r}\text { Minutes } \\
650\end{array}$ & Minutes & Minutes & $\begin{array}{l}\text { Hours } \\
45\end{array}$ & $\begin{array}{r}\text { Hours } \\
40\end{array}$ \\
\hline
\end{tabular}

TABLE 13.-Hearing-aid batteries

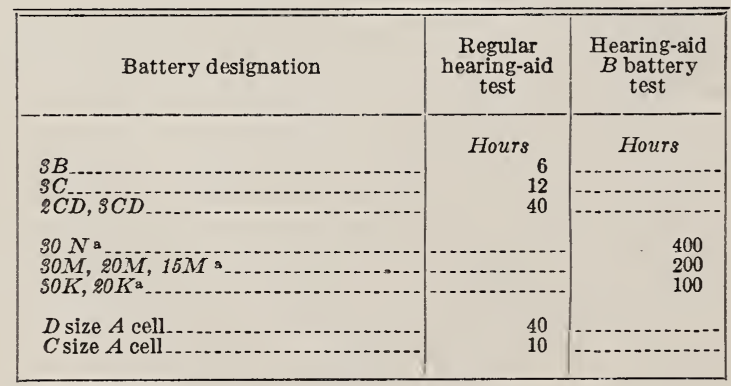

a Because of rapidly changing conditions incident to the development of the vacuum-tube instruments. the batteries here listed cannot be considered the only standard sizes. See table 5 . 
TABLE 14.-B batteries

\begin{tabular}{|c|c|c|c|}
\hline Battery designation & Test to be applied & $\begin{array}{l}\text { Initial } \\
\text { test } a\end{array}$ & $\begin{array}{l}6 \text { months } \\
\text { delayed } \\
\text { test } a\end{array}$ \\
\hline $90 N, 45 N$ & 5,000-ohm intermittent. & $\begin{array}{r}\text { Hours } \\
75 \\
60\end{array}$ & Hours $\begin{array}{r}65 \\
45\end{array}$ \\
\hline 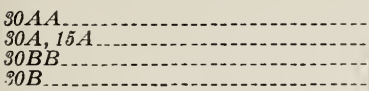 & 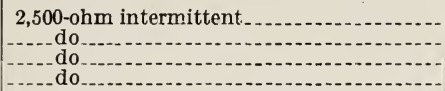 & $\begin{array}{r}50 \\
110 \\
125 \\
210\end{array}$ & $\begin{array}{r}45 \\
100 \\
115 \\
190\end{array}$ \\
\hline $30 D_{-}$ & $\left\{\begin{array}{l}2,500-0 h m \text { intermittent } \\
1,250 \text {-ohm intermittent }\end{array}\right.$ & $\begin{array}{l}300 \\
300\end{array}$ & 275 \\
\hline $30 F$ & 1,250-ohm intermittent. & $\begin{array}{l}550 \\
550\end{array}$ & $\begin{array}{l}490 \\
590\end{array}$ \\
\hline $60 D-F 18^{b} \ldots \ldots$ & $2,500-\mathrm{hm}$ intermittent & 600 & 550 \\
\hline
\end{tabular}

a To 15 volts for each $221 / 2$-volt unit.

$b$ The $A$ section of this $A-B$ pack shall conform to requirements in table 15 for battery $F 18$.

TABLE 15.-A batteries

\begin{tabular}{|c|c|c|c|c|}
\hline \multirow{2}{*}{ Battery designation } & \multicolumn{2}{|c|}{ 5-ohm $A$-battery test } & \multicolumn{2}{|c|}{ 25-ohm A-battery test } \\
\hline & 1.1 volts & 1.0 volt & 1.1 volts $a$ & 1.0 volt $a$ \\
\hline $\begin{array}{l}F 4 \\
F 8 \\
F 18\end{array}$ & $\begin{array}{r}\text { Hours } \\
85 \\
130 \\
170 \\
525\end{array}$ & $\begin{array}{r}\text { Hours } \\
115 \\
170 \\
230 \\
700\end{array}$ & \begin{tabular}{c|} 
Hours \\
\end{tabular} & $\begin{array}{c}\text { Hours } \\
\end{array}$ \\
\hline$S G \ldots \ldots$ & & & 130 & 160 \\
\hline${ }_{4} F 2 s, 4 F 2 d_{-} \ldots$ & & & 240 & 325 \\
\hline
\end{tabular}

a Cutoff voltage stated as volts per cell in series.

TABLE 16.-C batteries

\begin{tabular}{|c|c|}
\hline Designation & $\begin{array}{l}C \text {-battery } \\
\text { test }\end{array}$ \\
\hline$\Im B, 5 B, 15 B$ & $\begin{array}{r}\text { Months } \\
18 \\
24\end{array}$ \\
\hline
\end{tabular}

Washington, November 28, 1941. 


